\begin{tabular}{|c|c|}
\hline 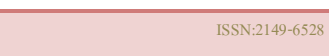 & \\
\hline $\begin{array}{c}\text { TOURISM } \\
\text { AND } \\
\text { MANAGEMENT } \\
\text { AN NTERNATONLL _OURNAL }\end{array}$ & $\begin{array}{l}\text { Journal of Tourism\&Management Research } \\
\text { ISSN: } 2149-6528 \\
2020 \text { Vol. 5, Issue.2 } \\
\text { http://ottomanjournal.com/index.html }\end{array}$ \\
\hline
\end{tabular}

\title{
Ozarks Ecotourism Conceptualization, Endowments and Trends: Practitioner Perspective
}

\begin{abstract}
Ecotourism development in the United States receives minimal attention despite the country being the birthplace of parks and a world leader in generating ecotourism consumers. Reports identify few ecotourism destinations in the U.S., none of which are located in Missouri or the Midwest. Recent effort by Missouri's tourism division attempts to promote the state as an ecotourism destination. However, questions remain whether the push is informed by economic motives rather than holistic understanding and appreciation of the ecotourism philosophy. This study investigates practitioners' conceptual understanding of the ecotourism philosophy. It also documents tourism trends and ecotourism endowments in Missouri Ozarks' region. Data were collected through questionnaire surveys, key informant interviews and field visits of protected areas. Findings show some conflicts and deficiencies in understanding of the ecotourism concept despite growing push for its development and rich nature base in the Ozarks. The study expects to inform ecotourism policy and build a better understanding of the concept of ecotourism among practitioners to support development of a competitive product in the Ozarks.
\end{abstract}

Keywords: Ecotourism, Missouri, sustainable tourism, Ozarks region, policy framework, practitioners

Jel Codes: Q01; Z32; Z3

Submitted:30/05/2020; Accepted:14/08/2020

Bernard M. Kitheka. Assistant Professor (Corresponding Author). Department of Kinesiology, Missouri State University. 910 S National Ave, Springfield MO 65897. USA. Phone: +1-417-836-4773 Email: mkitheka@missouristate.edu

Yating L. Davidson. Professor. Department of Kinesiology, Missouri State University. 910 S National Ave, Springfield MO 65897. USA. Phone: +1-417-836-4458

Email: yatingliang@missouristate.edu 


\section{Introduction}

Traveler consumer demand for 'natural' and 'remote' environments has been gaining prominence in the recent past. This increase has been associated with growth of environmentally conscious travelers, proliferation of eco-themed ventures, concerns for welfare of indigenous communities, and international pressure to develop sustainable forms of tourism (Cater, 1993; Honey, 2008). This eco-tourism phenomenon manifests more in the developing world (Krüger, 2005; Scheyvens, 1999; Spenceley \& Meyer, 2012), but destinations growing in more economically countries (Jones et al., 2009; Nepal, 2002). However, questions abound on factors behind the growth of ecotourism: Is it driven by 'green' trends and fads? Is there a genuine commitment to understand and embrace key tenets of ecotourism? Would delineating a concise definition aid in arriving at an ecotourism policy agenda and development framework? This study is mainly concerned with issues surrounding growth of ecotourism, and how the concept is viewed by key players including resource managers, policy makers and government employees in state of Missouri, United States.

The popularity of 'wilderness' areas and lands particularly occupied by indigenous people continues to take root in the outdoor recreation arena in the United States. With nearly $82 \%$ of the country's population urbanized (United Nations, 2014), undeveloped lands epitomize geographical isolation and a wildness feeling that cities and modern civilizations lack. Other people seeking nature-based experience in these remote areas are motivated by nostalgia with the hope that such a visit will give them a glimpse of the past they are hardly in touch with. Still, to others, just like the pioneers of the park movement (e.g. John Muir and Henry Thoreau), the undeveloped lands are imbued with psycho-spiritual and health and wellness endowments which inspire regular visits to natural areas (Kellert \& Wilson, 1995; Maller et al., 2008).

Approximately $7 \%$ of all international travelers pursue ecotourism experiences, with the most recent available statistics (though dated) showing that the United States contributes about $46 \%$ of the world's ecotourism consumers (Bryan, 2008; Honey, 2008). Further, although the United States is the birthplace of national parks and boasts some of the most visited protected areas globally (Honey, 2008), ecotourism development has not received sufficient attention. This despite a global shift from mass tourism towards sustainable forms of tourism like ecotourism - a sustained double-digit growth for three decades straight (Chand, 2020; Coria \& Calfucura, 2011; Fiorello \& Bo, 2012). Scattered reports identify only a few typical ecotourism destinations such as the Great Plains (Edwards, 2013; University of Nebraska, 2012) and America's 'Wild West' (Bryan, 2008). The main reason cited for a poor ecotourism product is the lack of a policy agenda and low level of public funding toward development and promotion of ecotourism and tourism in general (Honey, 2008). Evident also is still the relative low level of interest by scholars on ecotourism research (Bryan, 2008; Wight 1996). That aside, recent efforts in the state of Missouri show an interest in promoting the state as an ecotourism destination by the state's tourism agency (Missouri's Division of Tourism, MDT, 2016). But aspersions have been cast whether the push is driven primarily by economic bottom-lines (i.e. profit and revenues) motives and merely increasing visitor numbers rather than a holistic understanding and embrace of ecotourism and sustainable tourism best practices.

The current study investigated practitioners' understanding of the concept and philosophy of ecotourism in the state of Missouri. By documenting both reported and potential ecotourism sites and products, the study also evaluated the viability of ecotourism in the state's Ozark Mountains. Unlike many destinations, the United States has not adopted a definition or formal framework of ecotourism (Honey, 2008).

\subsection{Why a Definition?}


Definition of a contested concept like ecotourism is important because it could help in policy development (Fletcher \& Neves, 2012). This study expects to build a better understanding and appreciation of ecotourism among key stakeholders including practitioners and policy makers in the region and country. Being the first of its kind in this part of the country, the study illuminates ecotourism offerings in the region, which could be used to enhance the state's current efforts to develop alternative forms of tourism. The study expects to contribute to ecotourism literature in the United States in tandem with the closest neighbors (i.e. Canada and Mexico) and other western countries (e.g. Australia, Sweden and Norway) where substantial data exists and the industry is well-supported at public and private sector levels (Brenner \& Job, 2006; Cárdenas-Torres et al., 2007; De Los Monteros, 2002; Duchesne et al., 2000; Fennell, 1998; Hall, 2006).

Nearly four decades since the term was proposed, ecotourism, together with its root concepts of sustainable development (the changes that aim to harmonize economic, social and environmental goals) and sustainability (the outcome of sustainable development), still remains an abstract and elusive concept, leaving too much room for interpretation (Chandel \& Mishra, 2016; Donohoe \& Needham, 2006). The long-identified gap (e.g. Ross \& Wall, 1999) between ecotourism theory and ecotourism practice in many destinations is yet to be sealed. Besides the enduring confusion in definition and policy development, there is also growing fascination among academics, developers and consumers with the ecotourism niche. Many experts and practitioners present ecotourism as a viable alternative to mass tourism largely because it is usually small-scale, locally owned and more sustainable type of tourism (Bjork, 2007). From the demand perspective, travelers identifying themselves as 'ecotourists' normally pursue experiences that provide a sense of closeness to the natural environment and the host communities (Wood, 2002). From the supply side, the destination is a site primarily devoted to biodiversity conservation, providing opportunities to the visitor and public to experience nature (Fletcher \& Neves, 2012) while generating revenue to fund conservation initiatives and support nearby human communities (Donohoe \& Needham, 2006; Edwards, 2013). In terms of the offerings, Wood (2002) emphasizes that the ecotourism destination should: 1) possess natural features conserved within a protected landscape, 2) show evidence that tourism is not harming natural systems such as waterways, wetlands and wildlife habitats, 3) support thriving locally owned businesses, and, 4) offer affordable public facilities for tourists and locals. This enduring lack of clear definition hampers policy development and direction in implementation.

\section{Literature Review}

\subsection{Conceptualization of Ecotourism}

Since the 1990s, ecotourism is considered one of the fastest growing segments of tourism (Bjork, 2007; Weaver 2005). Arguably born in the late 1960 and early 1970s (Swarbrooke, 1999), and emerging in academic literature in the early 1980s primarily due to growing concerns of tourism's impact to the natural environments (Ceballos-Lascuraín, 1993), ecotourism is now a global phenomenon (Honey, 2008; Weaver, 2005). Ceballos-Lascurian (1996, p. 73) suggested one of the most used definitions of ecotourism: "traveling to relatively undisturbed or uncontaminated natural areas with the specific objectives of studying, admiring, and enjoying the scenery and its wild plants and animals, as well as any existing cultural manifestations (both past and present) found in these areas."

Popular viewpoints recognize ecotourism as a form of sustainable or responsible travel to natural areas that helps conserve natural resources upon which tourism is dependent while improving well-being of the local people (Coria \& Calfucura, 2011). From a business perspective, ecotourism is viewed as a small but rapidly growing sustainable tourism niche that is driven by free-market forces (Fletcher \& Neves, 2012; Sharpley, 2006) and consumerism (Fletcher \& Neves, 2012; Meletis \& Campbell, 2007). In terms of sustainable 
development, ecotourism is heavily governed by local and national regulations because of its perceived role in accelerating rural development and natural resource conservation (Cobbinah, 2016; Honey, 2008; Timothy \& White, 1999; Wood, 2002). These definitions and others suggest a balance between conservation and sustainable development aimed at improving wellbeing of residents and host communities (Acott et al., 1998; Braun et al., 2015; Seba, 2011). Ultimately, analysts seem to concur that ecotourism development should be about finding the synergy among tourism, environment and local people's welfare, where profit motives do not override the essential facets of the rural communities and the natural resources up which they depend (see Figure 1).

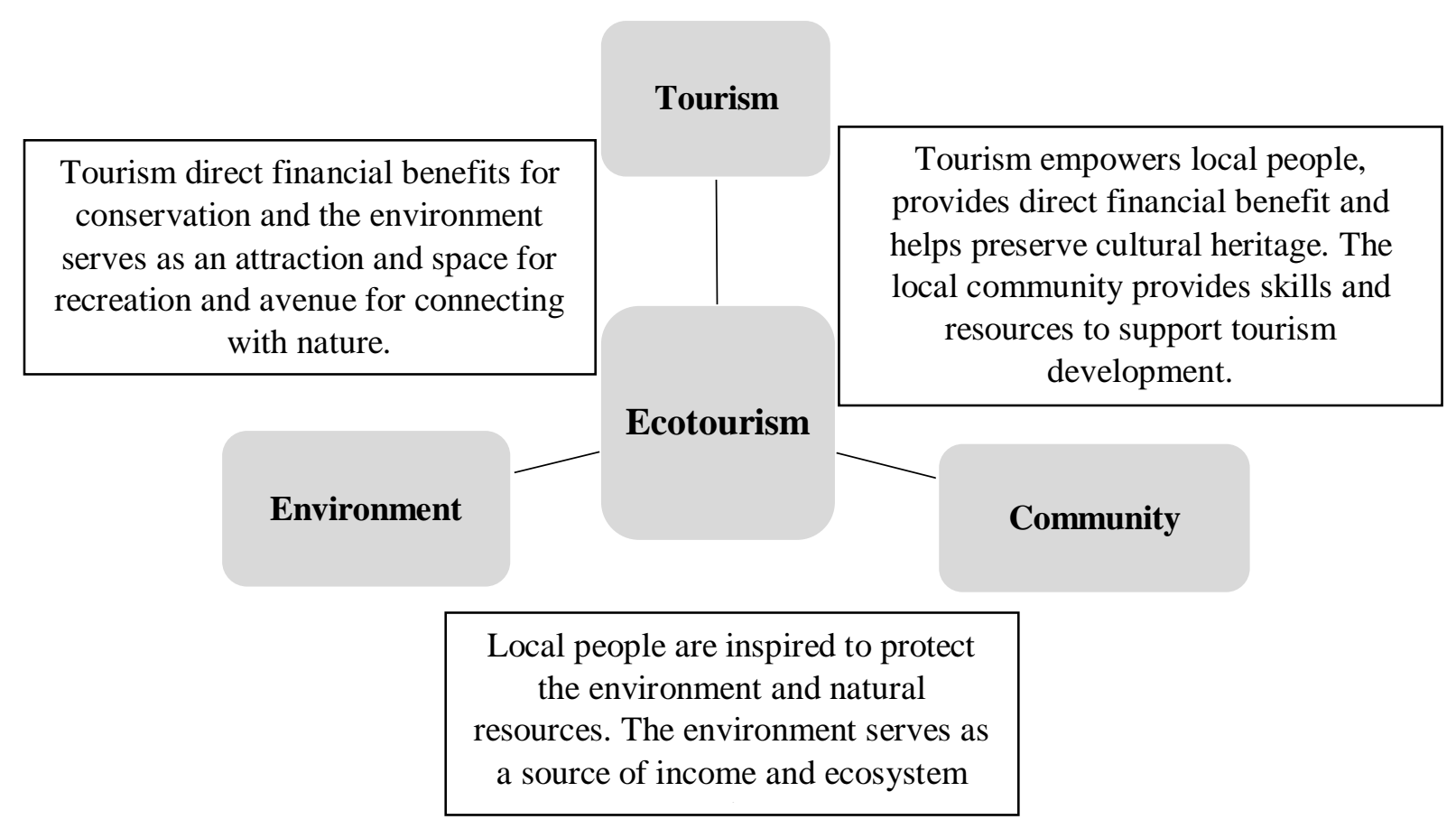

Figure 1: Ecotourism conceptualization.

Over the years, ecotourism, often used synonymously with (e.g. Ceballos-Lascuraín, 1996) or as a variant of nature-based tourism (e.g. Valentine, 1992; Nyaupane, 2007), has departed from focusing mainly on appreciation and care of the natural environment (Orams, 1995; Valentine, 1992) to embrace concerns for welfare of the local people, and education for the tourists and other stakeholders (Donohoe \& Needham, 2006; Vanderheiden \& Sisson, 2010). In support of this trend, Fennel (2001) identified key dimensions of ecotourism (Table $1)$ :

Table 1: Dimensions of ecotourism.

\begin{tabular}{ll}
\hline Dimension & Description \\
\hline Attraction anchors & Occurrence in nature or natural areas \\
Environmental sustainability & Commitment to conservation of natural resources \\
Cultural & Preservation and respect of indigenous cultures \\
Economic progress & Provision of tangible benefits to local communities \\
Education & Education and empowerment of all stakeholders \\
Management & Collaborative partnership \\
\hline Source: &
\end{tabular}

Source: Fennel (2001). 
Others have categorized ecotourism as either soft and hard core, or deep and shallow. Soft-core ecotourism is regarded, although still less negatively impactful, as closer to mass tourism in terms of numbers, preferences of facilities, interaction with nature and commitment to environment protection. Hard-core ecotourism is distinguished by the pursuit of strong connection to nature and believe that activities should enhance the natural resource base. Unlike soft-core ecotourists whose contact with nature is mediated through formal interpretation, tourists in this hard-core category embark on specialized trips and are more aware of their impacts and are less focused on their needs than wants (Laarman \& Durst 1987, Weaver \& Lawton 2002). On the other hand, deep ecotourism emphasizes nature's intrinsic value, the importance of community empowerment and involvement in decision making, and the preference for small-scale operations. Shallow ecotourism espouses management decisions based on utilitarian ethic towards nature and natural resources (Acott et al., 1998, Honey, 2008; Stem et al., 2003).

In this evolving definition, the natural environment is usually used to connote wild-life and supporting ecosystems, whereas the local people or host communities usually refer to indigenous communities in developing countries and specifically societies that depend heavily on nature based-tourism as source of livelihoods and socioeconomic wellbeing (CeballosLascuraín, 1996; Coria \& Calfucura, 2011). Although in theory nature-based tourism and ecotourism are treated different, in practice they are used interchangeably. In the present study, no distinction is made between the two concepts.

\subsection{Ecotourism Trends}

Many developing countries in Sub-Saharan Africa, Southeast Asia, the Caribbean, Central America, and South America depend heavily on nature-based tourist products, where in some cases it contributes up to $70 \%$ of the country's gross domestic product (GDP) (World Travel $\&$ Tourism Council WTTC, 2017). In these countries, tourism is the main generator of foreign currency and the leading source of employment for rural communities (Krüger, 2005). The increasing embrace of ecotourism by these destination-states is in large part because ecotourism is perceived as a viable tool for sustainable development, and a way to improve the welfare of the people who live adjacent to protected areas (Sharpley, 2006; Wearing \& Neil, 2009). Second, since it seeks to find harmony between conservation and travel, ecotourism is seen as an enduring form of tourism that can economically benefit local people and indigenous communities for many generations if they preserve their natural resources (Coria \& Calfuncura, 2011; Stem, et al., 2003; Wearing \& Neil, 2009).

Like many U.S. Midwest states, ecotourism is one of the focused areas Missouri is promoting for its tourism because of its vast natural resources. Ecotourism could be a valuable learning tool for sustainable development. Ecotourism brings the concept of sustainability into tourism through the promotion of economic and social development, without compromising the state of natural ecosystems and biodiversity (Kiper, 2013). However, for successful ecotourism development, it is important to develop a systematic policy framework, public support for certain types of recreation programs and adequate capacity of supporting services (Lararman \& Gregerson, 1994).

\subsection{Missouri's Tourism}

Tourism plays a major role in Missouri's economy, only behind manufacturing but ahead of agriculture (Missouri Department of Economic Development, MDED, 2017). With visitor numbers estimated at 42 million in 2017 (3.2\% increase from 2015), Missouri's tourism sector injected more than 17 billion dollars to the state economy (MDT, 2018). In terms of employment, 2016 estimates showed that approximately one in twelve of all jobs in the state were in tourism and service-related fields. In terms of source markets, $43.2 \%$ of the travelers originate from the state. Majority of the out-of-state visitors originate from the neighboring 
states, including Kansas, Illinois, Arkansas, Indiana, and Iowa. Missouri's international visitors emanate mostly from Canada (44.9\%), Mexico (10.9\%) and the United Kingdom (7.1\%) (MDT, 2015).

For mainstream mass tourism, St. Louis' Forest Park features prominently among other America's urban destinations (e.g. Central Park, New York and Golden Gate Park, San Francisco). St. Louis' Art Museum, Science Center and Planetarium, History Museum, and Zoo make the top list of other key tourist attractions that draw masses to the historic city (Holleman, 2016). Most visited urban destinations in Missouri include St. Louis area (25\%), Kansas City area (16.7\%), Branson (15.3\%), and Springfield 12.2\%) (MDT, 2018). For the segment of the visitors interested in nature and outdoor-based recreation, $12 \%$ tour historic sites, $12 \%$ visit state parks, $12 \%$ are attracted to scenic drives, $10 \%$ visit caves and $5 \%$ engage in biking and trail hiking (MDT, 2018). With over 150,000 acres available to the public for outdoor recreation and leisure consumption in form of parks, forests, historic sites and conservation areas, Missouri has one of the largest protected area systems in the United States. Each year, millions of people visit these outdoor spaces for passive and active recreation (Missouri State Parks, 2017b). The state's most-visited state parks include the Lake of the Ozarks, Table Rock, Bennett Springs, Ha-Ha Tonka and Montauk (Missouri State Parks, 2017a), all situated within the Ozarks ecosystem. The region's main wildlife interests include bison, wild horses, raptors, fish, bats, and amphibians (Notzke, 2016; Rikoon, 2006).

\subsection{Selection of the Study Site}

The current study was conducted in the Missouri's side of the Ozarks (see Figure 2). In terms of etymology, origins of the name Ozarks are contested. Widely accepted records show that Ozarks is a colonial term variously used to refer to either the Arkansas River, the Quapaw, or the Arkansas Post (Ketchell, 2007). Ketchell argues that in the late $19^{\text {th }}$ century, the term Ozarks was increasingly used as an adjective to refer to geological, commercial, cultural and civic aspects of the region. The Ozarks highlands area (see Figure 2) is the most extensive mountainous region between the Appalachians in the east and the Rocky Mountains in the west of the United States (Brandon \& Davidson, 2005). Its landscape is dominated by karst features including caves, springs, sinkholes and losing streams. Early to mid-20th century, numerous lakes were created along the creeks by damming streams and rivers for the dual purpose of flood control and power generation. The lakes significantly impacted the landscape and sociocultural and economic activities, most negative of them all being massive displacement of local people and loss of property (Campbell, Campbell \& Hughes, 2003; Watkins, 2006). Now the lakes and associated ecosystems are popular tourist destinations for outdoor and water-based recreation adventures.

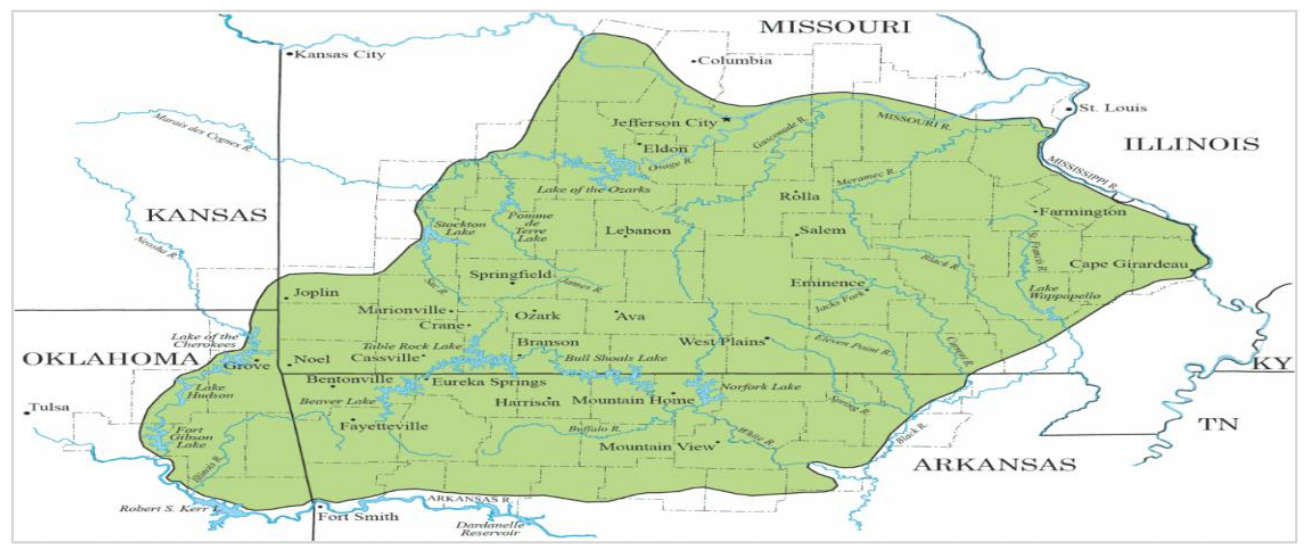

Figure 2: Map of the Ozarks.

Courtesy of Emily Burke, GGP Department, Missouri State University. 
No detailed study exists to show when and where tourism reportedly began in the Ozarks. However, the White River Railway, built early 1900s to connect Carthage MO and Newport AK, is credited to have facilitated growth of Ozarks' tourism (Morrow \& Myers-Phinney, 1999). Ketchell (2007) argues that the earliest recreation in the Ozarks was based on sport hunting and fishing following collapse of the once dominant lumber industry. Earliest visitors arrived in Branson area in search of places and characters first encountered in Harold Wright's classic novel Shepherd of the Hills (Ketchell, 2007). Many sites became associated with the novel, and these places would eventually develop to popular recreational attractions, which still welcome hundreds of thousands of visitors. Modern Ozarks' tourism is concentrated around its numerous man-made lakes, fish-filled rivers, and the Branson area (Morrow \& Myers-Phinney, 1999). Branson, because of to its strategic location in the heart of the Ozarks, the availabilities of indoor and outdoor entertainment theaters, and the presence of Silver Dollar City theme park, is an all-year-round tourism destination, welcoming about eight million visitors annually (Morgan, 2016). Apart from Branson, other prominent destinations include the Lake of the Ozarks, Big Springs, Round Springs, and Alley Springs (Halvorson \& Davis, 1996). Other Ozarks' outdoor travel and recreation activities are anchored by its extensive river-based protected area system, which were partly heralded by the creation of the Ozarks National Scenic Riverways in 1964 (Sarvis, 2002).

\section{Methodology}

\subsection{Study Design}

The study follows a mixed-method approach as recommended by Teddlie and Tashakkori (2003). Data were collected part concurrently and part sequentially using qualitative and quantitative instruments. Choice of these methods was to allow complementarity of data and to capture different voices and perspectives (Cresswell \& Clark, 2007; Teddlie \& Tashakkori, 2003). The qualitative sample is nested within the quantitative sample as suggested by Yin (2006). Both data were integrated in analysis and reporting. The quantitative instrument was developed following a feasibility study and discussions with a senior management team working for the Visitor and Convention Bureau in the city of Springfield, Missouri. A list of which parks and protected areas would be of interest to the study followed recommendations by staff at Missouri's divisions of state parks and tourism respectively.

\subsection{Data Collection}

Data were collected between fall 2016 and spring 2017 using multi-method approach including self-administered questionnaire surveys, expert interviews and field visits to preselected protected areas. The visited protected areas (including state parks, conservations areas and National Park Service units) are some of Ozark's top outdoor recreation sites as per data provided supplied by MDT (2018). Notably, Missouri has no national parks, but two units managed by the National Park Service (i.e. Ozarks National Scenic Riverways and Wilson Creek Battlefield) were included in the study.

Questionnaires were administered through an online protocol. A survey link was sent to a contact person (usually a key informant) in each participating target agency. The contact person then emailed the link to all the agency's staff. To participate, a candidate had to be 18 years and older. For semi-structured interviews, respondents (key informants) were conveniently selected and included agency directors, managers and/ or departmental heads working in the field of tourism and protected area management. Interviews, both individual and group, were conducted face-to-face using a semi-structured questionnaire. Interview sessions lasted between 35 and 75 minutes. The interviewees were selected owing to their position in the target organization or following recommendation by another key informant.

Participating agencies, all public or non-profit, were chosen because of their mandates; they work directly in tourism and/ or protected area management. The agencies included: 
Missouri State Parks department, Missouri Department of Tourism, Missouri Department of Conservation, Convention and Visitor Bureaus of Springfield, Jefferson City and Branson, and the National Park Service. In total, 74 employees completed the questionnaire and 17 key informants were interviewed. Detailed notes and analytical memos accompanied interviews and field visits as recommended by Saldana (2016). Thirteen parks and protected areas were visited with an aim of gaining first-hand experience of sites mentioned by literature and confirmed by interviewees as highly visited or having potential of developing as ecotourism sites. Further, selection of sites for visit was based on following criteria: 1) recommendation by key informant; 2) appearance on Missouri Division of Tourism's 2016 list of one of the most visited parks in Missouri, and, 3) proximity to Missouri State University - distance not exceeding 200-mile from the main campus in downtown Springfield, MO.

\subsection{Measurement of the Constructs}

For the survey, understanding of the theory and practice of ecotourism was measured using five items, all aimed at the respondent's understanding of the concept, and the impacts of tourism in general. Respondents rated each item on a five-type Likert scale $(1=$ Strongly disagree, $5=$ Strongly agree). The following items were assessed: level of awareness of Ozarks endowments and viability as an ecotourism destination; marketing and promotion of the Ozarks as an ecotourism destination; familiarity with Ozarks ecotourism offerings; and their frequency of travel to the Ozarks, respectively. In addition, respondents were given a list of activities and asked to select, without any ordering, the ones they felt aligned with the concept of ecotourism. Lastly, respondents were given a list of advertising mediums and asked to select which ones they regarded would be most effective in promoting Ozarks' ecotourism. The survey's demographic questions elicited information on the respondent's age, gender, job level or position and education level. The lead author developed all the questions in the survey questionnaire. The questions were then cross-checked and tested by a colleague before they were uploaded on-line.

For the semi-structured protocol, the researcher developed a list of questions seeking to engage key informants on general state of tourism in the state of Missouri, and their understanding and perceptions on the concept and practice of ecotourism. Interviews were conducted one-on-one or in group settings at respondents' respective workplaces. To triangulate and make the study more representative, the lead author visited sites mentioned during interviews to familiarize with the study site and enhance validity of the study.

\subsection{Data Analysis}

Survey data were analyzed using descriptive statistics. Employing MS Excel software, the survey data was sorted and analyzed quantitatively using frequency tables, pie charts and bar graphs as suggested by Taylor (2005). All data with zero (0) responses were eliminated in reporting. Interview data were coded manually, which involved finding themes and salience in individual narratives in detailed hand-written notes and analytical memos as suggested by Spencer and Ritchie (2002). Group interview scripts were first coded individually, and then all the codes were aggregated to find salience and build themes (Saldana, 2016). Themes of interest included ecotourism meaning, outdoor recreation patterns, ecotourism products, ecotourism destinations, and general tourism issues and trends in Missouri's Ozarks.

\section{Results}

\subsection{Participant Characteristics}

Usable questionnaire data were obtained from 76 participants $(65.3 \%$ female, $34.7 \%$ male). Age group representation included: 55 - 64 (27.8\%), followed by $35-44$ (25\%), $25-34$ $(23.6 \%)$, and $18-24(2.8 \%)$. The ages representation reflects the normal working ages in the United States, so no surprises that there was no representation 75 years and older. In terms of 
education, most participants' highest level of education was bachelor's degree $(50.7 \%)$, followed by graduate degree $(28.8 \%)$ and associate degree $(11 \%)$. Only about $10 \%$ indicated high school diploma as highest educational achievement. As for the key informant interviews, 16 (seven females and nine males) tourism and natural resource management professionals were interviewed. State Parks Division, the Division of Tourism and the National Park Service were each represented by three senior staff members, whereas the Department of Conservation and the Convention Visitor and Bureaus were each represented by four staff members. In reporting, interviewees were assigned codes M01 to M17 to protect their identity and maintain confidentiality. Regarding job position/level, most respondents were Managers (42.5\%) followed by Entry Level and Analyst/Associates (each 12.3\%). Those between Senior Manager and Directors each returned 8.2\%, whereas Vice Presidents and Presidents/CEOs levels combined registered 5.5\% representation.

\subsection{Understanding of the Concept of Ecotourism and its Impacts}

Respondents showed varying degrees of conceptual and practical understanding of the philosophy of ecotourism. In response to the question asking respondents to identify level of familiarity with the nature-based tourism offerings within the Ozarks, 32.9\% indicated Extremely Familiar, 34.2\% indicated Moderately Familiar and 29.0\% indicated Somewhat Familiar. None of the respondents selected non-familiarity.

From a list of tourism and outdoor recreation activities provided by the Division of Tourism, respondents were asked to select the ones that they readily associated with ecotourism. The most selected activities (see Table 2) were: wildlife viewing (92.8\%), hiking (92.8\%), canoeing (90.4\%), outdoor adventure (90.4\%) and camping (84.6\%). Others that showed high return included hunting and fishing (69.9\%), visiting historic sites $(56.2 \%)$ and volunteering $(28.8 \%)$. The remainder of the terms, mostly associated with city/urban-based tourism and recreation, was rated below $10 \%$.

Table 2: Degree of Ecotourism Understanding.

\begin{tabular}{ll}
\hline Activity Category & Responses $(\mathbf{n}=\mathbf{7 6})$ \\
\hline Wildlife viewing & $92.80 \%(\mathrm{n}=69)$ \\
Hiking & $92.80 \%(\mathrm{n}=69)$ \\
Visiting theme parks & $90.67 \%(\mathrm{n}=68)$ \\
Camping & $89.33 \%(\mathrm{n}=67)$ \\
Urban sightseeing & $82.67 \%(\mathrm{n}=62)$ \\
Hunting and fishing & $69.33 \%(\mathrm{n}=52)$ \\
Visiting historic sites & $57.33 \%(\mathrm{n}=43)$ \\
Volunteering & $29.33 \%(\mathrm{n}=22)$ \\
Clubbing & $17.33 \%(\mathrm{n}=13)$ \\
Visiting friends or family & $17.33 \%(\mathrm{n}=13)$ \\
Outdoor adventure & $10.67 \%(\mathrm{n}=8)$ \\
Shopping & $8.00 \%(\mathrm{n}=6)$ \\
Attending cultural events & $6.67 \%(\mathrm{n}=5)$ \\
Canoeing & $5.33 \%(\mathrm{n}=4)$ \\
Visiting museums & $2.67 \%(\mathrm{n}=2)$ \\
Fine dining & $0.00 \%(\mathrm{n}=0)$ \\
\hline
\end{tabular}

Most literature (e.g. Honey, 2008; Osland \& Mackoy, 2012; Reimer \& Walter, 2013; Wearing \& Neil, 2009) identifies education and conservation outreach, for both the tourists and host communities, as one of the key principles of ecotourism. Responding on whether 
tourists should be educated about the potential negative impacts of their travel to the environment and society, the following responses were noted: Strongly Agree (24.7\%), Moderately Agree (21.9\%) and Agree (38.4\%). Only less than 15\% of the respondents disagreed with the statement (Table 3).

Reflecting on tourism niches, most (82.9\%) survey respondents felt that, in practice, it was not always easy to differentiate between ecotourism and mainstream (mass) tourism. However, when asked to compare ecotourism and mass tourism, the majority $(68.6 \%)$ of the respondents agreed that the latter had more negative impacts than the former, which aligns with conventional views about ecotourism. Asked about contributions of tourism to climate change and global warming, most $(82.4 \%)$ respondents disagreed that tourism was a major contributor. Ironically, reflecting on potential of ecotourism to mitigate negative environmental impacts of tourism, a majority (81.2\%) responded in the affirmative. In terms of the general relationship between tourism and indigenous cultures, most respondents $(69.5 \%)$ agreed that tourism had more positive than negative impact. However, an overwhelming majority $(90.4 \%)$ indicated that travelers should be educated about indigenous communities and ways to respect their cultures. From the interview data, MO5 view of ecotourism phenomenon was that it was a:

"part of the green movement, which is driven by people's innate love for, and need to connect with nature in natural settings."

MO4's perspective was that other people were driven by the view and understanding of: "nature and parks being avenues for outdoor recreation and extreme sports, which accounts for the rapid growth of activities like rock climbing, zip-lining, mountain biking and multiplicity of water-based sports."

Both these views support the idea of ecotourism being based on instrumental value and enjoyment of nature and recreation activities that happen in natural settings. What is missing in the information collected is an understanding of who are considered local communities in the Ozark context, and what their overall aspirations are. With the United States nearly 85\% urbanized, it is not clear how to define 'local people' as presented in literature about this key stakeholder other countries or regions. Although there are many rural communities in the Ozarks region (including farmers, small business owners, etc.), interviewees did not reference these, rather there was more reference to people living in small towns and peri-urban communities visiting recreation areas and obtaining benefits such as seasonal employment.

\subsection{Ozarks Ecotourism Endowment and Opportunities}

On familiarity with the study site, respondents were asked to indicate how often they travel to or within the Ozarks for nature-based tourism or outdoor recreation purposes. The results were: $38.4 \%$ Very Often, $31.5 \%$ Often, $20.6 \%$ Sometimes, and $8.2 \%$ Rarely. Only a small minority indicated they had never traveled within the Ozarks for recreation-based engagements. Most (93.2\%) respondents generally Agreed or Strongly Agreed with the statement that the Ozarks is richly endowed with rich biodiversity to support a viable ecotourism industry (see Table 4).

Table 3: Level of agreement about tourism.

\begin{tabular}{lllllll}
\hline & $\begin{array}{l}\text { Strongly } \\
\text { disagree }\end{array}$ & $\begin{array}{l}\text { Moderately } \\
\text { disagree }\end{array}$ & Agree & $\begin{array}{l}\text { Moderately } \\
\text { agree }\end{array}$ & $\begin{array}{l}\text { Strongly } \\
\text { agree }\end{array}$ & Total \\
\hline $\begin{array}{l}\text { Natural resources are } \\
\text { negatively impacted by }\end{array}$ & $\begin{array}{l}10.67 \% \\
(\mathrm{n}=8)\end{array}$ & $\begin{array}{l}50.67 \% \\
(\mathrm{n}=38)\end{array}$ & $\begin{array}{l}12.00 \% \\
(\mathrm{n}=9)\end{array}$ & $\begin{array}{l}25.33 \% \\
(\mathrm{n}=19)\end{array}$ & $\begin{array}{l}1.33 \% \\
(\mathrm{n}=1)\end{array}$ & 75 \\
\end{tabular}

travel and recreation 


\begin{tabular}{|c|c|c|c|c|c|c|}
\hline $\begin{array}{l}\text { Tourism substantially } \\
\text { contributes to global } \\
\text { warming and climate } \\
\text { change. }\end{array}$ & $\begin{array}{l}36.84 \% \\
(\mathrm{n}=28)\end{array}$ & $\begin{array}{l}46.05 \% \\
(\mathrm{n}=35)\end{array}$ & $\begin{array}{l}9.21 \% \\
(\mathrm{n}=7)\end{array}$ & $\begin{array}{l}5.26 \% \\
(\mathrm{n}=4)\end{array}$ & $\begin{array}{l}2.63 \% \\
(\mathrm{n}=3)\end{array}$ & 76 \\
\hline $\begin{array}{l}\text { Ecotourism can help } \\
\text { mitigate negative } \\
\text { environmental impacts of } \\
\text { tourism. }\end{array}$ & $\begin{array}{l}5.63 \% \\
(\mathrm{n}=4)\end{array}$ & $\begin{array}{l}12.68 \\
(\mathrm{n}=9)\end{array}$ & $\begin{array}{l}45.07 \% \\
(\mathrm{n}=32)\end{array}$ & $\begin{array}{l}32.39 \% \\
(n=23)\end{array}$ & $\begin{array}{l}4.23 \% \\
(n=3)\end{array}$ & 71 \\
\hline $\begin{array}{l}\text { Tourists should be } \\
\text { educated about potential } \\
\text { negative impacts of their } \\
\text { travel. }\end{array}$ & $\begin{array}{l}6.67 \% \\
(\mathrm{n}=5)\end{array}$ & $\begin{array}{l}8.00 \% \\
(\mathrm{n}=6)\end{array}$ & $\begin{array}{l}37.33 \% \\
(\mathrm{n}=28)\end{array}$ & $\begin{array}{l}24.00 \% \\
(\mathrm{n}=18)\end{array}$ & $\begin{array}{l}24.00 \% \\
(n=18)\end{array}$ & 75 \\
\hline $\begin{array}{l}\text { Tourists should assume } \\
\text { responsibility for choices } \\
\text { they make during travel. }\end{array}$ & $\begin{array}{l}2.63 \\
(n=2)\end{array}$ & $\begin{array}{l}3.95 \% \\
(\mathrm{n}=3)\end{array}$ & $\begin{array}{l}21.05 \% \\
(\mathrm{n}=16)\end{array}$ & $\begin{array}{l}22.37 \% \\
(n=17)\end{array}$ & $\begin{array}{l}50.00 \% \\
(\mathrm{n}=38)\end{array}$ & 76 \\
\hline $\begin{array}{l}\text { In practice, there is no } \\
\text { difference between } \\
\text { ecotourism and mass } \\
\text { tourism. }\end{array}$ & $\begin{array}{l}16.67 \% \\
(12)\end{array}$ & $\begin{array}{l}63.89 \% \\
(\mathrm{n}=46)\end{array}$ & $\begin{array}{l}12.50 \% \\
(\mathrm{n}=9)\end{array}$ & $\begin{array}{l}2.78 \% \\
(\mathrm{n}=2)\end{array}$ & $\begin{array}{l}4.17 \% \\
(n=3)\end{array}$ & 72 \\
\hline $\begin{array}{l}\text { Tourism substantially } \\
\text { contributes to erosion of } \\
\text { indigenous cultures. }\end{array}$ & $\begin{array}{l}12.68 \% \\
(n=9)\end{array}$ & $\begin{array}{l}54.93 \% \\
(n=39)\end{array}$ & $\begin{array}{l}15.49 \% \\
(\mathrm{n}=11)\end{array}$ & $\begin{array}{l}15.49 \% \\
(n=11)\end{array}$ & $\begin{array}{l}1.41 \% \\
(\mathrm{n}=1)\end{array}$ & 71 \\
\hline $\begin{array}{l}\text { Travelers should be } \\
\text { educated on how to } \\
\text { respect indigenous } \\
\text { cultures. }\end{array}$ & $\begin{array}{l}4.00 \% \\
(n=3)\end{array}$ & $\begin{array}{l}5.33 \% \\
(\mathrm{n}=4)\end{array}$ & $\begin{array}{l}26.67 \% \\
(n=20)\end{array}$ & $\begin{array}{l}16.00 \% \\
(n=12)\end{array}$ & $\begin{array}{l}48.00 \% \\
(n=36)\end{array}$ & 75 \\
\hline $\begin{array}{l}\text { Ecotourism has more } \\
\text { positive impacts than mass } \\
\text { tourism. }\end{array}$ & $\begin{array}{l}5.56 \% \\
(\mathrm{n}=4)\end{array}$ & $\begin{array}{l}26.39 \% \\
(\mathrm{n}=19)\end{array}$ & $\begin{array}{l}34.72 \% \\
(n=25)\end{array}$ & $\begin{array}{l}18.06 \% \\
(n=16)\end{array}$ & $\begin{array}{l}15.28 \% \\
(\mathrm{n}=11)\end{array}$ & 2 \\
\hline
\end{tabular}

In terms of socio-cultural endowments, the majority (95\%) Agreed or Strongly Agreed that the Ozarks was rich in socio-cultural heritage to support ecotourism. Responding to overall viability of the Ozarks as an ecotourism destination, most (94.3\%) respondents chose Agree or Strongly Agree. In response to whether the Ozarks should be valued as a credible ecotourism destination, 95.8\% of the respondents' answers were between Agree and Strongly Agree, whereas in terms of whether the region is well-promoted as an ecotourism destination, $44.4 \%$ felt it was Moderately disagree followed by Agree (31.9\%).

Table 4: Level of agreement about ecotourism in the Ozarks.

\begin{tabular}{lllllll}
\hline & $\begin{array}{l}\text { Strongly } \\
\text { disagree }\end{array}$ & $\begin{array}{l}\text { Moderately } \\
\text { disagree }\end{array}$ & Agree & $\begin{array}{l}\text { Moderately } \\
\text { agree }\end{array}$ & $\begin{array}{l}\text { Strongly } \\
\text { agree }\end{array}$ & Total \\
\hline $\begin{array}{l}\text { The Ozarks is endowed } \\
\text { with rich biological } \\
\text { diversity to support }\end{array}$ & $\begin{array}{l}5.33 \% \\
(\mathrm{n}=4)\end{array}$ & $\begin{array}{l}1.33 \% \\
(\mathrm{n}=1)\end{array}$ & $\begin{array}{l}28.00 \% \\
(\mathrm{n}=21)\end{array}$ & $\begin{array}{l}24.00 \% \\
(\mathrm{n}=18)\end{array}$ & $\begin{array}{l}41.33 \% \\
(\mathrm{n}=31)\end{array}$ & 75 \\
$\begin{array}{l}\text { Ecotourism. } \\
\text { The Ozarks is well- }\end{array}$ & $\begin{array}{l}1.39 \% \\
\mathrm{n}=1)\end{array}$ & $\begin{array}{l}44.44 \% \\
(\mathrm{n}=32)\end{array}$ & $\begin{array}{l}31.94 \% \\
(\mathrm{n}=23)\end{array}$ & $\begin{array}{l}22.22 \% \\
(\mathrm{n}=16)\end{array}$ & $\begin{array}{l}0.00 \% \\
(\mathrm{n}=0)\end{array}$ & 72 \\
promoted as an & & & & &
\end{tabular}


ecotourism destination.

The Ozarks is a viable ecotourism destination.

The Ozarks has a rich cultural heritage.

There is no need to brand the Ozarks as an ecotourism destination.

$\begin{array}{ll}\begin{array}{l}1.39 \% \\ (\mathrm{n}=1)\end{array} & \begin{array}{l}4.17 \% \\ (\mathrm{n}=3)\end{array} \\ 1.39 \% & 2.63 \% \\ (\mathrm{n}=1) & (\mathrm{n}=2) \\ & \\ \begin{array}{l}1.39 \% \\ (\mathrm{n}=1)\end{array} & \begin{array}{l}2.63 \% \\ (\mathrm{n}=2)\end{array}\end{array}$

$38.89 \%$

$29.17 \%$

$(\mathrm{n}=28) \quad(\mathrm{n}=21)$

$26.39 \%$

$(\mathrm{n}=19)$

$26.32 \%$

$17.11 \%$

$52.63 \%$

$(\mathrm{n}=40)$

$24.66 \%$

$(\mathrm{n}=13)$

$46.58 \%$

$24.66 \%$

$(\mathrm{n}=18)$

$(\mathrm{n}=34)$
72

76

73

Interview data mirrored survey data, with most respondents acknowledging Ozarks natural and cultural endowments and opportunities in developing an ecotourism product. Readily identified opportunities included public and privately managed lands such as parks, conservation areas, trails, greenways and historic sites. Frequently mentioned commercial recreation properties that provide outdoor or vicarious nature-based experiences included the Dogwood Canyon and the Wonders of Wildlife Aquarium. Respondent MO4 observed that:

"the Ozarks is steeped in rich cultural heritage including associations with Mark Twain and the Shepard of the Hills, which enhance the cultural narrative of the region."

That aside, MO3 raised concerns on how to tell the history and cultural heritage of the Ozarks, and also what a typical 'local community' was:

"it is difficult to tell the history and culture of the United States; how do you package in tourism contexts?"

Further, M02 identified special conservation education and outreach opportunities such as the:

\section{"partnership between Bass-Pro and the Springfield Public Schools}

that offers semester-long classes for fifth graders on natural resource management."

Respondent M017 underscored the potential in the younger generation, particularly millennials and post-millennials, in advancing the cause for outdoor recreation and naturebased tourism in the Ozarks:

"Nature is coming back to the forefront of attractions because the millennial generation are more interested in nature and outdoor recreation activities such as hiking, camping, mountains biking and paddle boarding. They are not afraid of the outdoors; they are not afraid to get a tick on them."

\subsection{Promoting Ecotourism in the Ozarks}

More than $50 \%$ of the respondents disagreed that most people traveling to the Ozarks were aware of the region's ecotourism endowments (Table 5). Moreover, when asked to indicate whether there was a need to promote the Ozarks as ecotourism destination, over $70 \%$ selected between Agree and Strongly Agree. Concurring with the survey data, most experts acknowledged Ozarks endowments and hence the need for development and promotion the region as an ecotourism destination.

Table 5: Level of agreement on marketing and promotion of ecotourism in the Ozarks.

\begin{tabular}{llllll}
$\begin{array}{l}\text { Strongly } \\
\text { disagree }\end{array}$ & $\begin{array}{l}\text { Moderately } \\
\text { disagree }\end{array}$ & Agree & $\begin{array}{l}\text { Moderately } \\
\text { agree }\end{array}$ & $\begin{array}{l}\text { Strongly } \\
\text { agree }\end{array}$ & Total \\
\hline
\end{tabular}




\begin{tabular}{|c|c|c|c|c|c|c|}
\hline $\begin{array}{l}\text { Most travelers in the } \\
\text { region are aware of the } \\
\text { Ozarks being an } \\
\text { ecotourism destination. }\end{array}$ & $\begin{array}{l}9.59 \% \\
(\mathrm{n}=7)\end{array}$ & $\begin{array}{l}41.10 \% \\
(\mathrm{n}=30)\end{array}$ & $\begin{array}{l}35.62 \% \\
(\mathrm{n}=26)\end{array}$ & $12.33 \%(\mathrm{n}=9)$ & $\begin{array}{l}1.37 \% \\
(\mathrm{n}=1)\end{array}$ & 73 \\
\hline $\begin{array}{l}\text { The Ozarks region is well- } \\
\text { marketed as an } \\
\text { Ecotourism destination. }\end{array}$ & $\begin{array}{l}8.22 \% \\
(\mathrm{n}=6)\end{array}$ & $\begin{array}{l}52.05 \% \\
(\mathrm{n}=38)\end{array}$ & $\begin{array}{l}28.77 \% \\
(\mathrm{n}=21)\end{array}$ & $10.96 \%(n=8)$ & $\begin{array}{l}0.00 \% \\
(\mathrm{n}=0)\end{array}$ & 73 \\
\hline $\begin{array}{l}\text { There is need to promote } \\
\text { the Ozarks as an } \\
\text { Ecotourism destination. }\end{array}$ & $\begin{array}{l}5.41 \% \\
(n=4)\end{array}$ & $\begin{array}{l}16.22 \% \\
(n=12)\end{array}$ & $\begin{array}{l}48.65 \% \\
(n=36)\end{array}$ & $14.86(n=11)$ & $\begin{array}{l}14.86 \% \\
(n=11)\end{array}$ & 74 \\
\hline $\begin{array}{l}\text { Marketing and promoting } \\
\text { ecotourism in the Ozarks } \\
\text { is blatant green-washing. }\end{array}$ & $\begin{array}{l}33.85 \% \\
(\mathrm{n}=22)\end{array}$ & $\begin{array}{l}50.77 \% \\
(\mathrm{n}=33)\end{array}$ & $\begin{array}{l}6.15 \% \\
(n=4)\end{array}$ & $7.69 \%(n=5)$ & $\begin{array}{l}1.57 \% \\
(\mathrm{n}=1)\end{array}$ & 65 \\
\hline
\end{tabular}

In response to what would be the most effective medium for promoting ecotourism in the Ozarks, social media scored highest (93.0\%), followed closely by internet advertising (e.g. on company websites, etc.) (80.3\%), print media $(74.7 \%)$, word of mouth $(71.8 \%)$, visitor centers (63.4\%) and mass media (see Figure 3). The least preferred mediums were direct mail, fairs and special events. Lastly, most $(84.1 \%)$ respondents disagreed with the statement 'marketing or promoting ecotourism in the Ozarks would be tantamount to green-washing, seemingly validating ecotourism potential of the region (see Figure 3).

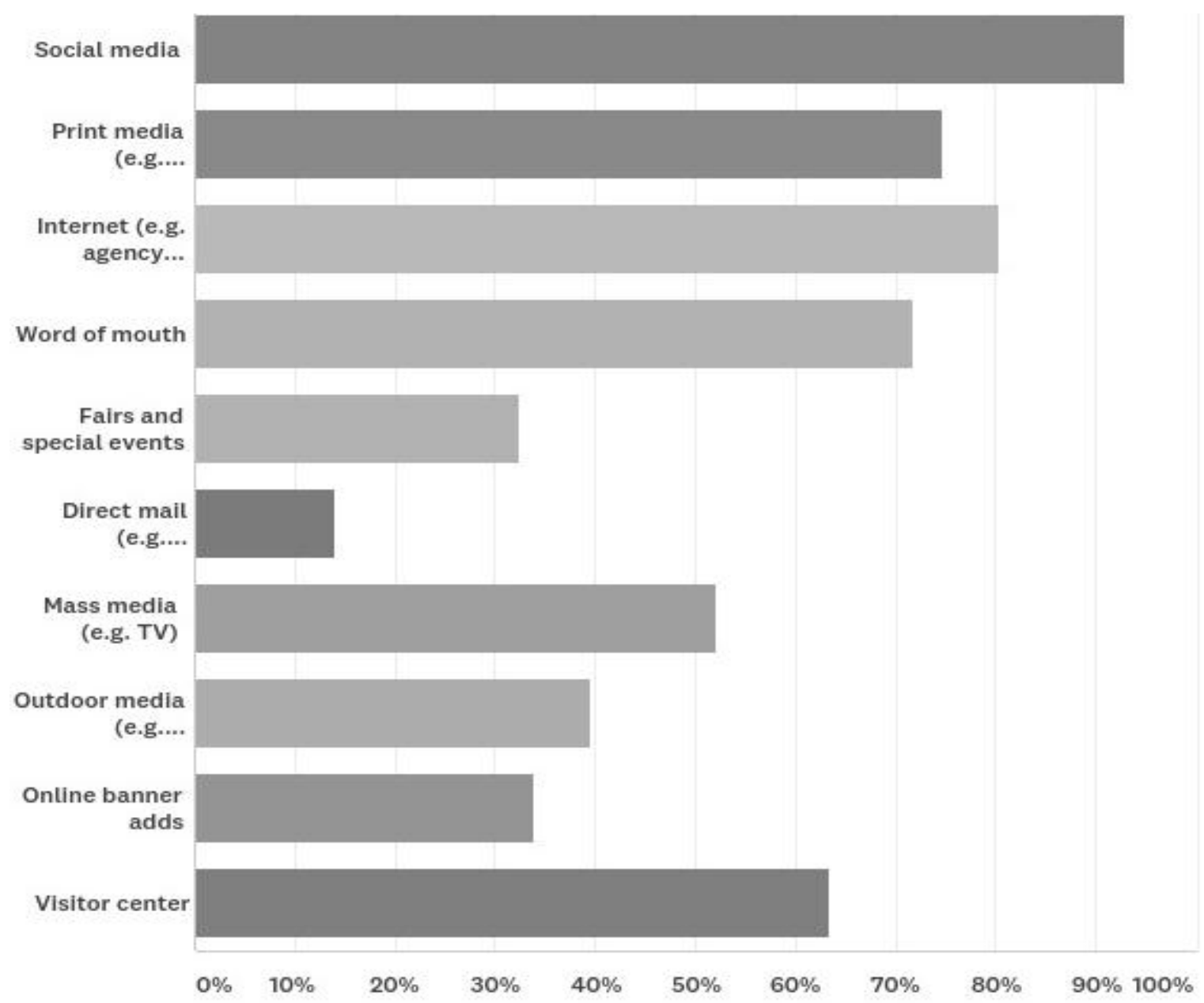

Figure 3: Best way to promote the Ozarks as an ecotourism destination. 
Respondent MO4 emphasized the position of tourism as a:

"major revenue generator for the state, which enables the Division of

Tourism to attract state funding to promote sustainable forms of

tourism and support research efforts by scholars and graduate students."

However, interviewees from other state agencies and departments decried the low level of funding from government to support tourism research and promotion. It was widely acknowledged that lack of exposure of Ozarks tourism offerings to the international market was a major factor contributing to poor levels of visitation beyond Missouri's neighboring states.

Most of the practitioners registered their desire and commitment to see Missouri and Ozarks' tourism grow, especially travelers seeking outdoor recreation experiences and connections with nature. MO2 noted:

"visitors are looking for authentic experiences that connect them to nature and the region. We need to get something that wows the people and deliver our conservation message." However, MO2 lamented the "lack of funding for marketing and promotion tourism in general from the federal government, which has makes the USA lag behind many countries in terms of the national government investing in the tourism industry."

\section{Conclusion, Implications and Limitations}

Ecotourism development process is a lengthy and long-term process, which requires a sustained effort from all those involved to yield tangible benefits in the long term (Roxana, 2012). It has taken close to four decades for ecotourism develop as a viable product for many destinations around the world. Missouri is just in the beginning stage, and thus still "muddling-through" without a clear plan or strategy. Findings of this research demonstrated that professionals recognized the importance of ecotourism and its potential to contribute to conservation, sociocultural and economic development to rural communities. The challenge is how to gain support for such a 'new' type of development if many communities do not fully comprehend all the facets that are involved. For rural and semi-urban Midwest communities that are keen on improving their socioeconomic welfare together with preservation of nature and the regions' cultural heritage, ecotourism could be a perfect medium. Successful ecotourism development could provide incentives for other natural resources conservation and alternative nature-based enterprises that are less harmful to the environment. Further, the positive economic impact of ecotourism could be a starting point to convince governing agencies and administration to invest resources to develop a framework to support ecotourism development. Although print media is still popular, electronic word of mouth is the trend and future of tourism. Therefore, marketing and promotion of ecotourism should focus more on reaching the target market through social media and other internet platforms since that is where the traffic is headed.

The conflict between economic bottom-lines of natural resource extraction, overexploitation and overconsumption must be resolved with ethics and values of conservation. It is also important to find a balance between positive and negative impacts of tourism to protected areas and human communities such as hunting, fishing, logging and infrastructure development. Aspirations of rural communities living adjacent protected areas, such farmers, should also be take into consideration. For example, the state of Queensland, Australia developed a set of guidelines for best practices in ecotourism in 2015, which involved the following: compatibility with cultural and natural values, appropriate fit within characteristics of the sites, environmentally friendly operational practices, active engagement with owners and locals, overall positive enhancement, and increased appreciation and 
protection of the resources (Queensland Government, 2015). For regions and communities lacking an ecotourism policy development framework like the Missouri and the Ozarks, these guides and criteria could be used as a reference point.

Government-led ecotourism development and marketing could also be impacted by multiple factors. For example, Lee \& Choi (2017) studied the stakeholder's views, particularly government officials, on the reduction of governmental support for ecotourism in South Korea. The research found that the more experience managers have with managing ecotourism activity itself, the less supportive they are of external support and rapid economic growth at the expense of the environment. Lee \& Choi $(2017$, p. 7) assert that "in order to ensure long-term environmental conservation and economic sustainability, policy changes should not lead to the replacement of existing personnel or dependence on governmental support." The strength of policy and stability personnel, especially those who understand various facets of ecotourism development, are important factors in the continuing development of the sector.

Findings from this study suggest a limited agency understanding of the concept of ecotourism and its underpinning principles among tourism and natural resource management professionals in Missouri. Respondent's views of ecotourism were mostly conventional (dependent on and enhanced by nature) but depart from the mainstream definition in part because a significant majority considers hunting and fishing (consumptive use of wildlife) as ecotourism. This latter view is supported by a few other scholars (e.g. Meletis \& Campbell, 2007) who argue that controlled hunting and fishing can increase ecotourism's socioeconomic gains too, and thus support conservation by the local people. In terms of the consumer profile, data suggest that a typical Ozark ecotourism leans more towards soft-core nature-based tourism with potential explanation being a product that is poorly differentiated and promoted, or some level of ignorance from the consumer. Lacking in the Ozark ecotourism conversation was the dimension of host communities as stakeholders and direct beneficiaries of ecotourism development. This is, however, consistent to development discourses in countries that are highly urbanized when trying to conceptualize who constitutes a 'local community', and what their role is (see e.g. Fletcher, 2014).

Findings show that the Ozarks is endowed with diverse ecosystems, wildlife, landscapes, and cultural heritage to support ecotourism development. Respondents were also of the opinion that, unlike other equally endowed destinations, the Ozarks does not get the attention it deserves nationally among scholars and practitioners in terms of research, promotion, and media coverage. Simply the Ozark's has no recognized brand and thus has no face. Participants suggested that the relevant authorities should promote the region more aggressively and capitalize on emerging technologies and online platforms like social media. There should also be more partnership among key stakeholders in terms of funding and collaboration for research.

Generally, there are growing shifts in the United States to appreciate and invest in alternative forms of tourism. As a result of this shift, new destinations have been emerging, which are pursuing tourism niches that are anchored on sustainable development principles (e.g. ecotourism and agritourism). One such is the recent effort to develop and formally recognize the city of Vail, Colorado, as the first sustainable tourism destination in the country (see Blevins, 2017). Ecotourism products and destinations are also prominently mentioned west of the Rocky Mountains (e.g. Bryan, 2008; Dangi \& Gribb, 2018). Further, efforts are underway to develop Jackson Hole WY as the next accredited sustainable tourism destination in the United States.

Despite the lack of consensus in definition, ecotourism is with us for the foreseeable future, therefore failure to engage or provide direction by key players including experts, policy makers and academics, on its conceptualization and operationalization is not an option. First, if planners and policy makers can conceptually show an understanding of ecotourism as 
well as an appreciation of the validity of ecotourism as a global force especially its role in fostering sustainable development, then the push for developing ecotourism in the United States is a tenable proposition. A strong correlation exists (e.g. Donohoe \& Needham, 2006; Hall, 2006) between conceptual understanding of ecotourism and ecotourism policy, operationalization and setting of standards. Furthermore, data showing that the United State is the world's leading source market of ecotourism consumers should provide extra impetus to define the product and promote it locally and abroad. A thriving ecotourism sectors could provide additional incentive for legislative support to set aside more protected areas in Missouri especially following recent stripping of protected area status from some of the state parks. As an alternative to concocting a national definition of ecotourism in sync with other countries and regions, relevant stakeholders could embark on a country-wide collaborative agenda to delineate ecotourism's scope to provide more synergy in establishing a framework for policy development.

Third, with tourism's continued hold on the top second position globally in terms of revenue generation, and the forecast that tourism will become Missouri's number one industry (MDED, 2017), the Ozarks can play a leading destination in attracting ecotourism consumers and investors. With thoughtful and timely positioning, the Ozarks region could also serve as the first recognized Midwest ecotourism (or sustainable tourism) destination just as the city of Vail in Colorado that has taken the tag of the country's first sustainable tourism destination. That being said, in line with global trends, there are no promises or expectations that ecotourism will surpass mainstream tourism in the near future. For Missouri, mainstream tourism destinations such as Branson, owing to its location at the heart of the Ozarks and with its ever popular urban tourist attraction and nearby theme park, will still remain the bedrock and motivation of travel and tourism in the region.

Lastly, since many practitioners agreed that many people visiting the region are oblivious or ignorant of the region's natural attractions, more funding is needed to promote the Ozarks as a competitive outdoor destination beyond the current reach of nearby cities. The state's relevant destination management authorities could take advantage of the widely acknowledged growing consciousness among leisure travelers of the need to protect the natural environment and enhancement of the well-being of the rural communities that live adjacent protected areas. In summary, our findings suggest that:

- A definition of ecotourism is important for policy and regulation frameworks.

- Understanding and appreciation of ecotourism can provide basis for operationalization.

- Demarcating principles of ecotourism can help in guiding development of ethics and standards.

- Appreciation of ecotourism could lead to more interest and support for research among scholars.

- Target marketing using social media and internet platforms can help reach more potential ecotourism consumers.

This preliminary study on Ozarks' ecotourism highlights important issues from the perspective of tourism and protected area managers mostly working for the public sector. The study adds value to the conversation about ecotourism in the United States. With an expectation that more researchers will show interest in the subject, the current work could open more possibilities for knowledge transfer, policy development and operationalization.

Unlike interview data which managed to capture the diversity of voices in terms of level of management and number of agencies represented, the survey responses were less representative. Employees of Missouri State Parks department and the National Park Service (NPS) failed to participate in the survey because of management changes. This study, thus, although relevant in understanding how relevant practitioners' view ecotourism in Missouri, the findings are not generalizable. Future research should consider government procedures 
and plan accordingly. Further, to capture a more representative picture on Ozarks' ecotourism and its potential, plan for a future study is underway that include the private sectors, travelers, and the local communities. Sampling for questionnaire survey will also include employee in Missouri State Park and National Park Service systems that were missed in this study. With additional studies, a better understanding of the region's ecotourism development will be achieved.

\section{References}

Acott, T. G., Trobe, H. L., \& Howard, S. H. (1998). An evaluation of deep ecotourism and shallow ecotourism. Journal of Sustainable Tourism, 6(3), 238-25.

Bjork, P. (2007). Definition paradoxes: from concept to definition. In J. Higham (Ed.) Critical issues in ecotourism: Understanding a complex tourism phenomenon (pp. 23-45). Boston, MA: BH Elsevier.

Blevins, J. (2017, July). Can the town of Vail become country's first sustainable tourism destination? Retrieved August from http://www.denverpost.com/2017/07/28/vail-firstsustainable-tourism-destination/.

Brandon, J. C., \& Davidson, J. M. (2005). The landscape of Van Winkle's Mill: Identity, myth, and modernity in the Ozark Upland South. Historical Archaeology, 39(3), 113131.

Braun, Y. A., Dreiling, M. C., Eddy, M. P., \& Dominguez, D. M. (2015). Up against the wall: ecotourism, development, and social justice in Costa Rica. Journal of Global Ethics, 11(3), 351-365.

Brenner, L., \& Job, H. (2006). Actor-management of protected areas and ecotourism in Mexico. Journal of Latin American Geography, 5(2), 7-27.

Bryan, W.L. (2008). Can sustainable travel exist in a developed country? In Stronza, A., \& Durham, W. H. (Eds.). Ecotourism and conservation in the Americas (Vol. 7, pp, 93113). Cambridge, MA: CABI.

Campbell, R. R., Campbell, M., \& Hughes, C. (2003). A revolution in the heartland: Changes in rural culture, family and communities 1900-2000. Columbia, MO: Missouri University Extension.

Cárdenas-Torres, N., Enríquez-Andrade, R., \& Rodríguez-Dowdell, N. (2007). Communitybased management through ecotourism in Bahia de los Angeles, Mexico. Fisheries Research, 84(1), 114-118.

Cater, E. (1993). Ecotourism in the third world: Problems for sustainable tourism development. Tourism Management, 14(2), 85-90.

Ceballos-Lascurain, H. (1993). Ecotourism as a worldwide phenomenon. In: K. Lindberg, \& D. Hawkins (Eds.), Ecotourism: A guide for planners and managers (pp. 12 - 14). North Bennington: The Ecotourism Society.

Ceballos-Lascurain, H. (1996). Tourism, ecotourism, and protected areas: The state of nature-based tourism around the world and guidelines for its development. Cambridge, UK: IUCN.

Chand, N. N. (2020). Ecotourism in New Zealand: A Catalyst for Sustainable Development (Doctoral dissertation, Auckland University of Technology).

Chandel, A., \& Mishra, S. (2016). Ecotourism revisited: Last twenty-five years. Czech Journal of Tourism, 5(2), 135-154.

Che, D. (2006). Developing ecotourism in first world, resource-dependent areas. Geoforum, $37(2), 212-226$.

Cobbinah, P. B. (2015). Contextualising the meaning of ecotourism. Tourism Management Perspectives, 16, 179-189.

Coria, J., \& Calfucura, E. (2011). Ecotourism and the development of indigenous communities: The good, the bad, and the ugly. Ecological Economics, 73, 47-55. 
Cresswell, J. W., \& Clark, V. P. (2007). Designing and conducting mixed methods research. Thousand Oaks, CA: Sage.

Dangi, T. B., \& Gribb, W. J. (2018). Sustainable ecotourism management and visitor experiences: Managing conflicting perspectives in Rocky Mountain National Park, USA. Journal of Ecotourism, 17(3), 338-358.

De Los Monteros, R. L. E. (2002). Evaluating ecotourism in natural protected areas of La Paz Bay, Baja California Sur, Mexico: Ecotourism or nature-based tourism? Biodiversity \& Conservation, 11(9), 1539-1550.

Donohoe, H. M., \& Needham, R. D. (2006). Ecotourism: The evolving contemporary definition. Journal of Ecotourism, 5(3), 192-210.

Duchesne, M., Côté, S. D., \& Barrette, C. (2000). Responses of woodland caribou to winter ecotourism in the Charlevoix Biosphere Reserve, Canada. Biological Conservation, 96(3), 311-317.

Edwards, R. (2013). Can ecotourism save the prairies? Retrieved from: https://www.unl.edu/ plains/ecotourism-prairie-fire.pdf

Fennell, D. A. (1998). Ecotourism in Canada. Annals of Tourism Research, 25(1), 231-235.

Fennell, D. A. (2001). A content analysis of ecotourism definitions. Current Issues in Tourism, 4(5), 403-421.

Fiorello, A., \& Bo, D. (2012). Community-based ecotourism to meet the new tourist's expectations: An exploratory study. Journal of Hospitality Marketing \& Management, 21(7), 758-778

Fletcher, R. (2014). Romancing the wild: Cultural dimensions of ecotourism. Duke University Press.

Fletcher, R., \& Neves, K. (2012). Contradictions in tourism: The promise and pitfalls of ecotourism as a manifold capitalist fix. Environment and Society, 3(1), 60-77.

Hall, C. M. (2006). Policy, planning and governance in ecotourism. In S. Gossling and J. Hultman (Eds.), Ecotourism in Scandinavia: lessons in theory and practice (pp. 193206). Cambridge, MA: CABI.

Halvorson, W.L. \& Davis, G.E. (1996). Science and ecosystem management in the national parks. Tucson, AZ: University of Arizona Press.

Holleman, J. (2016). Forest Park tops USA Today list of urban parks. Retrieved from http://www.stltoday.com/lifestyles/columns/joe-holleman/forest-park-tops-usa-todaylist-of-urban-parks/article_e0b396a8-685b-5a78-a376-45b6b3af9396.html

Honey, M. (2008). Ecotourism and sustainable development: who owns paradise? $2^{\text {nd }}$ Ed. Washington, DC: Island Press.

Jones, T., Wood, D., Catlin, J., \& Norman, B. (2009). Expenditure and ecotourism: predictors of expenditure for whale shark tour participants. Journal of Ecotourism, 8(1), 32-50.

Kellert, S. R., \& Wilson, E. O. (Eds.). (1995). The biophilia hypothesis. Washington, D.C.: Island Press.

Ketchell, A.K. (2007). Holy Hills of the Ozarks: religion and tourism in Branson, Missouri. Baltimore, MD: John Hopkins University Press.

Kiper, T. (2013). Role of ecotourism in sustainable development. Advances in Landscape Architecture, Murat Özyavuz, IntechOpen, DOI: 10.5772/55749.

Krüger, O. (2005). The role of ecotourism in conservation: panacea or Pandora's Box? Biodiversity \& Conservation, 14(3), 579-600.

Laarman, J. \& Durst P. (1987). Nature travel and tropical forests. Raleigh: FREI working paper series, southeastern center for forest economics research. Research Triangle Park, N.C: Southeastern Center for Forest Economics Research.

Lararman, J \& Gregerson, H. (1994). Making nature-based tourism contribute to sustainable development: A policy framework. A USAID-funded global program, the 
Environmental and Natural Resources Policy and Training Project. The U.S. Forest Service.

Lascurain, H. C. (1988). The future of ecotourism. Mexico Journal, 1, 13-14.

Lee, J. \& Choi, H. (2017). Stakeholders' views on reducing financial support in governmentled ecotourism areas. Ocean \& Coastal Management, 144, 7-15.

Maller, C., Townsend, M., Brown, P., \& St Leger, L. (2002). Healthy parks, healthy people: the health benefits of contact with nature in a park context: a review of current literature. Melbourne, Australia: Parks Victoria, Deakin University Faculty of Health \& Behavioural Sciences.

MDED (Missouri Department of Economic Development). (2017). Missouri economic report 2017. Retrieved from https://www.missourieconomy.org/pdfs/2017_MO_ Economic_Report.pdf

MDT (Missouri Division of Tourism). (2015). Missouri tourism: impact s and opportunities. Retrieved from http://www.ttra.com/assets/1/7/Missouri_Tourism_Impact_ and_Opportunities.pdf

MDT (Missouri Division of Tourism). (2016). 10 state parks you must visit. Retrieved from https://www.visitmo.com/missouri-travel/10-state-parks-you-must-visit.aspx

MDT (Missouri Division of Tourism). (2018). https://mdt-visitmo-cdn.s3.amazonaws.com /industry-files/annual-reports/1555106172-mdt-annual-report-fy18.pdf

Mehmetoglu, M. (2005). A case study of nature-based tourists: Specialists versus generalists. Journal of Vacation Marketing, 11(4), 357-369.

Meletis, Z. A. \& Campbell, L. M. (2007). Call it consumption! Re-conceptualizing ecotourism as consumption and consumptive. Geography Compass, 1(4), 850-870.

Missouri State Parks. (2017A). Missouri state park attendance. Retrieved August 22, 2017 from https://mostateparks.com/sites/mostateparks/files/FINAL_2016_Attendance.pdf.

Missouri State Parks. (2017B). About the Missouri State Park System. Retrieved from https://mostateparks.com/page/55047/about-missouri-state-park-system

Morgan, M. (2016). Billboards and tourism in the Missouri Ozarks: boon or blight? Tourism Analysis, 21(6), 675-680.

Morrow, L. \& Myers-Phinney, L. (1999). Shepherd of the hills country: Tourism transforms the Ozarks, 1880-1930s. Fayetteville, AK: University of Arkansas Press.

Nepal, S. K. (2002). Mountain ecotourism and sustainable development: Ecology, economics, and ethics. Mountain Research and Development, 22(2), 104-109.

Notzke, C. (2016). Wild horse-based tourism as wildlife tourism: The wild horse as the other. Current Issues in Tourism, 19(12), 1235-1259.

NPS (National Park Service). (2017). More than just the rivers. Retrieved from https:// www.nps.gov/ozar/index.htm

Nyaupane, G.P. (2007). Ecotourism versus nature-based tourism: Do tourists really know the difference? Anatolia: An International Journal of Tourism and Hospitability Research, 18(1), 161-165.

Orams, M. B. (1995). Towards a more desirable form of ecotourism. Tourism Management, 16(1), 3-8.

Osland, G. E., \& Mackoy, R. D. (2012). Education and ecotourism: A framework and analysis of education in ecolodges in Costa Rica and Panama. European Journal of Tourism, Hospitality and Recreation, 3(1), 77.

Queensland Government. (2015). Best practice ecotourism development guidelines. Retrieved from https://www.ecotourism.org.au/assets/Resources-Hub-Ecotourism-Plans/BestPractice-Ecotourism-Development-Guidelines-2015.pdf

Rayburn-Trobaug, C. (2018). Ecotourism in the U.S. Retrieved fromhttp://traveltips.usatoday. com/ ecotourism-us-10980.html 
Reimer, J. K., \& Walter, P. (2013). How do you know it when you see it? Community-based ecotourism in the Cardamom Mountains of southwestern Cambodia. Tourism Management, 34, 122-132.

Rikoon, J. S. (2006). Wild horses and the political ecology of nature restoration in the Missouri Ozarks. Geoforum, 37(2), 200-211.

Ross, S., \& Wall, G. (1999). Ecotourism: towards congruence between theory and practice. Tourism management, 20(1), 123-132.

Roxana, D.M. (2012). Considerations about ecotourism and nature-based tourism - realities and perspectives. International Journal of Academic Research in Economics and Management Sciences, 1(5), 215-221.

Saldana, J. (2016). The coding manual for qualitative researchers $\left(3^{\text {rd }}\right.$ ed.). Thousand Oaks, CA: Sage.

Sarvis, W. (2002). A Difficult Legacy: Creation of the Ozark National Scenic Riverways. The Public Historian, 24(1), 31-52.

Scheyvens, R. (1999). Ecotourism and the empowerment of local communities. Tourism Management, 20(2), 245-249.

Seba, J. (2011). Ecotourism and sustainable tourism: New perspectives and Studies. Oakville, Canad: Apple Academic Press.

Sharpley, R. (2006). Ecotourism: A consumption perspective. Journal of Ecotourism, 5(1-2), 7-22.

Spenceley, A., \& Meyer, D. (2012). Tourism and poverty reduction: Theory and practice in less economically developed countries. Journal of Sustainable Tourism, 20(3), 297317.

Spencer, L., \& Ritchie, J. (2002). Qualitative data analysis for applied policy research. In A. Bryman and B Burgess (Eds.), Analyzing qualitative data (pp. 187-208). London, UK: Routledge.

Stem, C. J., Lassoie, J. P., Lee, D. R., Deshler, D. D., \& Schelhas, J. W. (2003). Community participation in ecotourism benefits: The link to conservation practices and perspectives. Society \&Natural Resources, 16(5), 387-413.

Swarbrooke, J. (1999). Sustainable Tourism Management. Wallingford: CAB International.

Taylor, G. R. (Ed.). (2005). Integrating quantitative and qualitative methods in research. Lanham, MD: University Press of America.

Teddlie, C., \& Tashakkori, A. (2003). Major issues and controversies in the use of mixed methods in the social and behavioral sciences. In A. Tashakkori \& C. Teddlie (Eds.), Handbook of mixed methods in social \& behavioral research (pp. 3-50). Thousand Oaks, CA: Sage.

Timothy, D. J., \& White, K. (1999). Community-based ecotourism development on the periphery of Belize. Current Issues in Tourism, 2(2-3), 226-242.

United Nations. (2014). World Urbanization Prospects: The 2014 Revision, Highlights (ST/ESA/SER.A/352). Retrieved January 22, 2019 from: https://esa.un.org/unpd /wup/publications/files/wup2014-highlights.pdf

University of Nebraska. (2012). Great Plains Center announces top 10 ecotourism sites in region. Retrieved from http://newsroom.unl.edu/releases/2012/09/13/ Great+Plains+Center+announces+top+10+ecotourism+sites+in+region

Valentine, P. (1992). Nature based tourism. In B. Weiler \& C. M. Hall (Eds.), Special Interest Tourism (pp. 105-127). London, UK: Bellhaven Press.

Vanderheiden, S., \& Sisson, M. (2010). Ethically responsible leisure? Promoting social and environmental justice through ecotourism. Environmental Philosophy, 7(2), 33-47.

Watkins, C. (2006). The Meramec Basin Project: a look back 25 years later. Ozarks Mountain experience. Article 69 \& 70 Combined. Retrieved from: 
https://web.mst.edu/ rogersda/ meramec_basin_prj/meramec_basin_prj-aeg_revised_for_web.pdf

Wearing, S. \& Neil, J. (2009). Ecotourism: impacts, potentials and possibilities, $2^{\text {nd }}$ Ed. Oxford, UK: BH Elsevier.

Weaver, D. B. (2005). Comprehensive and minimalist dimensions of ecotourism. Annals of Tourism Research, 32(2), 439-455.

Weaver, D. B., \& Lawton, L. J. (2002). Overnight ecotourist market segmentation in the Gold Coast hinterland of Australia. Journal of Travel Research, 40(3), 270-280.

Wight, P. A. (1996). North American ecotourists: Market profile and trip characteristics. Journal of Travel Research, 34(4), 2-10.

Wood, M. (2002). Ecotourism: Principles, practices and policies for sustainability. Nairobi, Kenya: UNEP.

Yin, R. K. (2006). Mixed methods research: Are the methods genuinely integrated or merely parallel. Research in the Schools, 13(1), 41-47.

\section{Author Biography}

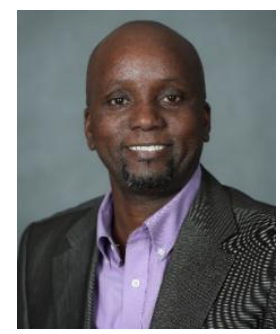

Dr. Bernard Kitheka is an assistant professor at Missouri State University. His research and teaching interests include sustainable tourism, ecotourism, human dimensions of parks and recreation, urban sustainability, and sustainable development.

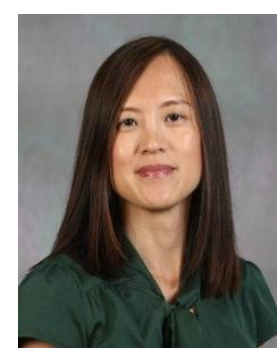

Dr. Yating "Tina" Liang is a professor in Recreation, Sport, and Park Administration program of Department of Kinesiology at Missouri State University. Her main research area includes event management, leisure behavior, and tourism. 